\title{
Nitrogen Doping Effects on Carbon Nanotubes and the Origin of the Enhanced Electrocatalytic Activity of Supported Pt for Proton-Exchange Membrane Fuel Cells
}

\author{
Yougui Chen, ${ }^{\dagger}$ Jiajun Wang, ${ }_{\S}^{\dagger}$ Hao Liu, ${ }^{\dagger}$ Mohammad Norouzi Banis, ${ }_{\S}^{\dagger}$ Ruying Li, ${ }^{\dagger}$ Xueliang Sun, ${ }^{*},+$ \\ Tsun-Kong Sham, ${ }^{\neq}$Siyu Ye, ${ }^{\circ}$ and Shanna Knights ${ }^{\S}$ \\ ${ }^{\dagger}$ Department of Mechanical and Materials Engineering, University of Western Ontario, London, Ontario, Canada N6A 5B9 \\ ${ }^{\ddagger}$ Department of Chemistry, University of Western Ontario, London, Ontario, Canada N6A 5B7

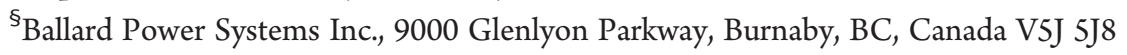 \\ Supporting Information
}

ABSTRACT: Carbon nanotubes (CNTs) and nitrogen-doped carbon nanotubes $(\mathrm{CNx})$ were synthesized by the floating catalyst chemical vapor deposition (FCCVD) method. Pt nanoparticles were deposited onto the two catalyst supports with the ethylene glycol reduction method. Different from CNTs that contain straight hollow tubes, $\mathrm{CNx}$ contain a bamboolike structure with kinks along the tubes and more surface defects. X-ray photoelectron spectroscopy (XPS) confirms the nitrogen atoms in the graphite matrix and reveals the chemical natures of the doped nitrogen atoms. Carbon K-edge near-edge X-ray absorption fine structure (NEXAFS) and Raman characterizations reveal higher defectiveness in $\mathrm{CNx}$ than $\mathrm{CNTs}$. The unique structure and surface property of CNx leads to a better dispersion of Pt nanoparticles on CNx than on CNTs, as revealed by TEM images. Pt supported on $\mathrm{CNx}(\mathrm{Pt} / \mathrm{CNx})$ exhibited a higher electrochemical surface area $(\mathrm{ECSA})$ and higher catalytic activity toward oxygen reduction reaction (ORR), in comparison to Pt supported on CNTs (Pt/CNTs). Better performance of Pt/CNx than $\mathrm{Pt} / \mathrm{CNT}$ s has been confirmed by single-cell fuel cell tests.

\section{INTRODUCTION}

Because of the depletion of fossil fuels and rising environmental pollutions, fuel cells have attracted attention from governments and industries as an important clean energy alternative in the future. Among various fuel cells, proton-exchange membrane fuel cell (PEMFC) is the most developed in the past two decades, featuring rapid start-up and high power density, making it suitable for many applications including stationary and automotive applications. ${ }^{1}$ Despite these advantages, low durability $^{2}$ and high cost ${ }^{3}$ still hamper its widespread commercialization. It is well-known that all these disadvantages are directly related to the catalysts used in PEMFC to catalyze oxygen reduction (ORR) and hydrogen oxidation reactions.

Until now, the state-of-the-art catalyst involves Pt nanoparticles supported on carbon black (e.g., Vulcan XC 72). As a catalyst support, in spite of its high surface area and good electrochemical performance, carbon black is still unsatisfactory. Because of the weak interaction between Pt and carbon black, Pt nanoparticles aggregate into larger particles or dissolve into the polymer electrolyte, which results in a decrease in Pt surface area and fuel cell performance. ${ }^{4}$ Furthermore, Pt nanoparticles deposited within the porous carbon nanostructure may be inaccessible to the

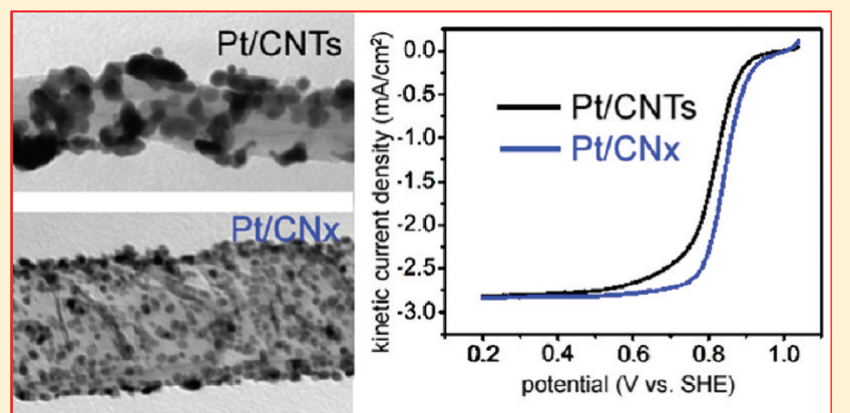

polymer electrolyte and hence reduce the utilization of $\mathrm{Pt}^{5}$ In addition, carbon black suffers from corrosion (to form surface oxides and/or even $\mathrm{CO}$ and $\mathrm{CO}_{2}$ evolution) at the cathode of the PEMFC, ${ }^{6-8}$ where there is high potential, moisture, and perhaps hydrogen peroxide. Therefore, a tremendous effort is being devoted to the development of better catalyst support materials.

Recently, novel carbon nanostructure materials such as carbon nanotubes (CNTs) have attracted great attention as promising catalyst supports. The smooth graphitic surface could make all Pt nanoparticles on CNTs accessible to the reactants. The high surface area of CNTs with their unique nanostructure could lead to a high dispersion of $\mathrm{Pt}$ nanoparticles. Additionally, due to the graphitic structure, CNTs maintain high electrical conductivity and corrosion resistance; both of which are critical for an excellent catalyst support. It has been shown that CNTs are better catalyst supports than conventional carbon black. CNTs exhibit higher electrochemical corrosion resistance than carbon black. ${ }^{9,10}$ Furthermore, Pt supported on CNTs (Pt/CNTs) also show a higher

Received: September 16, 2010

Revised: January 12, 2011

Published: February 14, 2011 
electrocatalytic activity ${ }^{11-15}$ and stability ${ }^{10,16}$ than Pt/C. In spite of these advantages, the uniform dispersion of $\mathrm{Pt}$ nanoparticles onto CNTs still remains a formidable challenge because of the inert surface of CNTs. Therefore, harsh chemical or electrochemical oxidations applied with concentrated strong acid are typically employed to create oxygen-containing surface functionalities, which facilitate the attachment of Pt nanoparticles. ${ }^{17}$ However, these severe treatments also significantly deteriorate the preferred structure and electrical properties of CNTs due to the destruction of the graphitic structure. ${ }^{18}$

Alternatively, doping with foreign atoms (e.g., nitrogen) represents a feasible path to increase reactivity toward the deposition of metal nanoparticles. The doping of nitrogen in CNTs creates defects that break out the chemical inertness of pure CNTs, yet preserves the electrical conductivity. Nitrogen-doped carbon nanotubes $(\mathrm{CNx})$ contain nitrogenated sites that are chemically active. Therefore, it should be possible to avoid those detrimental functionalization processes using strong acid and to attach Pt nanoparticles onto the surface of $\mathrm{CNx}$ effectively. In addition, nitrogen-doped carbon itself has a certain activity toward ORR. ${ }^{19,20}$ Recently, CNx have been reported as support materials in fuel cell catalysts. ${ }^{2-24}$ Our preliminary work indicates that $\mathrm{CNx}$ works better as catalyst supports than CNTs in PEMFC in terms of better Pt dispersion and thus higher fuel cell performance. ${ }^{21}$ Besides the superior performance, Pt supported on $\mathrm{CNx}(\mathrm{Pt} / \mathrm{CNx})$ has been shown to exhibit a higher durability both by theoretical calculations $\mathrm{s}^{25,26}$ and by our experimental work. ${ }^{27}$

Because the sluggish kinetics of the ORR has been a major bottleneck in the performance of PEMFCs, the current work focuses on the cathode. We have reported a preliminary study on $\mathrm{Pt}$ nanoparticles deposited on a $\mathrm{CNx} /$ carbon paper composite electrode of an enhanced activity compared with $\mathrm{CNTs}$ /carbon paper. ${ }^{21}$ Here, systematic experiments were conducted to investigate the nitrogen doping effects on CNTs and the enhanced electrocatalytic activity of powder $\mathrm{Pt} / \mathrm{CNx}$ catalysts. A comprehensive understanding of the nitrogen doping effects on CNTs and the origin of enhanced activity of the deposited Pt emerges.

\section{EXPERIMENTAL SECTION}

2.1. Synthesis of CNTs and CNx. CNTs and CNx were grown directly on carbon paper via the floating catalyst chemical vapor deposition (FCCVD) method in a horizontal quartz tube furnace system, as described before in detail. ${ }^{28}$ In short, a carbon paper with a $30 \mathrm{~nm} \mathrm{Al} \mathrm{buffer} \mathrm{layer} \mathrm{was} \mathrm{applied} \mathrm{as} \mathrm{the} \mathrm{substrate.}$ Ethylene and ferrocene were used as the carbon source and catalyst precursor, respectively. CNTs were synthesized at $850{ }^{\circ} \mathrm{C}$ with a gas flow of ethylene $(10 \mathrm{sccm})$ and $\operatorname{Ar}(500 \mathrm{sccm})$. Ferrocene decomposed into iron, which deposited onto the carbon paper and acted as the catalyst for CNTs growth. Two grams of melamine was employed as the nitrogen precursor for the synthesis of CNx. At $950^{\circ} \mathrm{C}$, melamine decomposed into nitrogen atoms, which were incorporated into the graphite structure during the growth of CNTs to yield CNx.

2.2. Pt Deposition. Pt nanoparticles were deposited on the pristine CNTs (or $\mathrm{CNx}$ ) by the ethylene glycol reduction method at a Pt metal loading of $30 \mathrm{wt} \%{ }^{29}$ Typically, $15 \mathrm{mg}$ of CNTs (or CNx) were dispersed in ethylene glycol with ultrasonication. Then $17.1 \mathrm{mg}$ of $\mathrm{H}_{2} \mathrm{PtCl}_{6} \cdot 6 \mathrm{H}_{2} \mathrm{O}$ was added into the suspension. After refluxing at $160^{\circ} \mathrm{C}$ for $3 \mathrm{~h}$, the suspension was cooled down to room temperature naturally. The catalysts were collected with filtration and washed with ample deionized water. The colorless and transparent filtrate indicated that all of the $\mathrm{H}_{2} \mathrm{PtCl}_{6} \cdot 6 \mathrm{H}_{2} \mathrm{O}$ was reduced into Pt metal and deposited on CNTs (or $\mathrm{CNx}$ ). The Pt/CNTs (or Pt/CNx) thus obtained was dried at $60{ }^{\circ} \mathrm{C}$ overnight.

2.3. Physical Characterizations. The morphologies of $\mathrm{CNTs}$ and $\mathrm{CNx}$ were characterized with field emission scanning electron microscopy (SEM, Hitachi S-4800, $5 \mathrm{kV}$ ). The structures of CNTs and CNx and the dispersion of Pt on both of them were investigated with transmission electron microscopy (TEM, Philips CM10, $80 \mathrm{kV}$ ). High-resolution TEM (HRTEM) images were obtained with a JEOL 2010F microscope, operating at 200 kV. X-ray photoelectron spectroscopy (XPS, Kratos Axis Ultra Al, alpha, $14 \mathrm{kV}$ ) was applied for the analysis of nitrogen in the CNx. Raman data were obtained with a Horiba Jobin Yvon high-resolution (HR800) confocal Raman spectrometer, which operates with an incident laser beam at $632.8 \mathrm{~nm}$. Measurements of the carbon K-edge near-edge X-ray absorption fine structure (NEXAFS) of the nanotubes were conducted at the spherical grating monochromator (SGM) beamline of the Canadian Light Source, a 2.9 GEV third generation synchrotron source.

2.4. Electrochemical Characterizations. The electrochemical characterizations were conducted in a thermostatted standard three-compartment electrochemical cell using a ring-disk electrode setup with a bipotentiostat (Model PGSTAT-30, Ecochemie, Brinkman Instruments) and rotation control (Pine Instruments). Pt wire and $\mathrm{Ag} / \mathrm{AgCl}(3 \mathrm{M} \mathrm{NaCl})$ served as the counter and reference electrode, respectively. For convenience, all potentials in this paper are referenced to standard hydrogen electrode (SHE).

The working electrode was prepared as follows. Five milligrams of catalyst (Pt/CNTs or Pt/CNx) were suspended in $1 \mathrm{~mL}$ of 2-propanol solution containing $20 \mu \mathrm{L}$ of a 5 wt \% Nafion solution (Ion Power Inc., USA) with ultrasonication to achieve a uniform ink. The catalyst thin film was prepared by casting $20 \mu \mathrm{L}$ of the ink onto a glassy carbon electrode $(5 \mathrm{~mm}$ in diameter, Pine Instruments). The electrode was dried at $60^{\circ} \mathrm{C}$ for $10 \mathrm{~min}$.

The catalytic activity for the ORR was evaluated with a rotating ring-disk electrode (RRDE, Pine Instruments). Before testing began, the electrode was cycled in $\mathrm{Ar}$ saturated $0.5 \mathrm{M} \mathrm{H}_{2} \mathrm{SO}_{4}$ solution until steady-state cyclic voltammetry was reached. $\mathrm{O}_{2}$ was then bubbled for $30 \mathrm{~min}$ to achieve saturation. With gentle $\mathrm{O}_{2}$ bubbling, RRDE tests were conducted at $5 \mathrm{mV} / \mathrm{s}$ with a rotation speed of $1600 \mathrm{rpm}$ (revolution per minute). The gold ring was set at $1.2 \mathrm{~V}^{30}$ where the $\mathrm{H}_{2} \mathrm{O}_{2}$ formed on the disk during oxygen reduction is readily reoxidized. All of the electrochemical experiments were performed at $25^{\circ} \mathrm{C}$.

2.5. Membrane-Electrode Assemble (MEA) Fabrication and Single Fuel Cell Test. Before the MEA fabrication, the electrolyte membrane (Nafion 112, DuPont Inc., USA) was pretreated according to the following three steps. First, the membrane was cleaned by immersion in a $3 \% \mathrm{H}_{2} \mathrm{O}_{2}$ aqueous solution at $90^{\circ} \mathrm{C}$ for $1 \mathrm{~h}$. Second, after rinsing with deionized water, it was boiled in $1 \mathrm{M} \mathrm{H}_{2} \mathrm{SO}_{4}$ for $1 \mathrm{~h}$. Finally, the membrane was rinsed and boiled in deionized water to remove $\mathrm{H}_{2} \mathrm{SO}_{4}$ completely.

An ink of the catalysts and Nafion solution (3:1 in weight ratio of catalyst to dry Nafion) in iso-propanol was prepared with ultrasonication and pasted on the gas diffusion electrode (E-TEK Division, PEMEAS Fuel Cell Technologies, Somerset, NJ, USA) at a Pt loading of $0.2 \mathrm{mg} / \mathrm{cm}^{2}$. Afterward, it was dried in a vacuum oven at $90^{\circ} \mathrm{C}$ for $3 \mathrm{~h}$. A Nafion layer was then brushed on the top of the catalysts at $0.6 \mathrm{mg} / \mathrm{cm}^{2}$. The prepared electrode was dried 

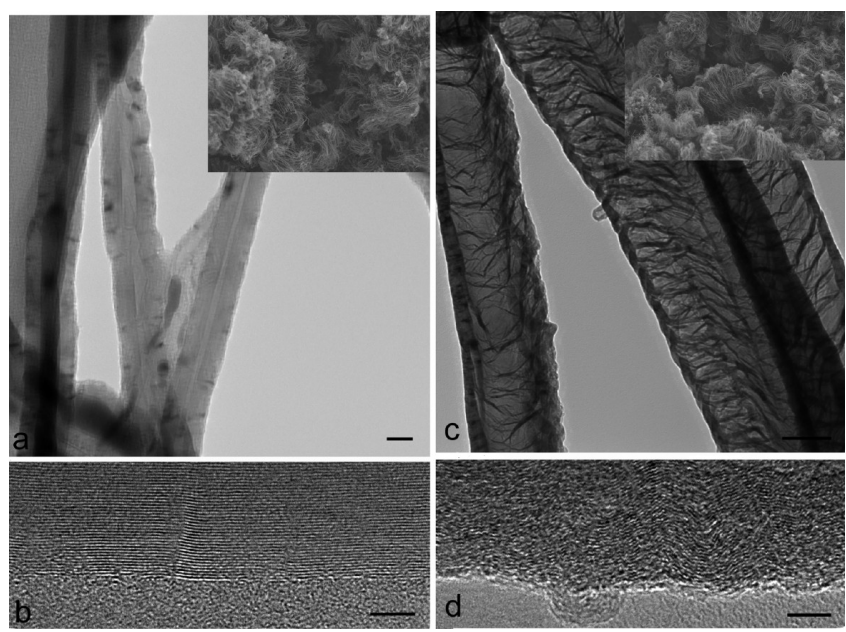

Figure 1. TEM and HRTEM images of CNTs ( $a$ and $b)$ and $\mathrm{CNx}(\mathrm{c}$ and d), inserts: the corresponding SEM images. Scale bars: $20 \mathrm{~nm}$ in a; $100 \mathrm{~nm}$ in $\mathrm{c} ; 5 \mathrm{~nm}$ in $\mathrm{c}$ and $\mathrm{d}$.

in vacuum oven at $90^{\circ} \mathrm{C}$ for $1 \mathrm{~h}$ and was then ready for MEA fabrication.

With the standard gas diffusion electrode $\left(0.5 \mathrm{mg}_{\mathrm{Pt}} / \mathrm{cm}^{2}\right.$, E-TEK Division, PEMEAS Fuel Cell Technologies, Somerset, NJ, USA) as the anode, the prepared electrode as the cathode, and Nafion 112 as the membrane, the MEA was hot pressed at $135^{\circ} \mathrm{C}$ and 150 psi for $2 \mathrm{~min}$.

All of the MEAs were tested at $80{ }^{\circ} \mathrm{C}$, with both $\mathrm{H}_{2}$ and $\mathrm{O}_{2}$ at a flow rate of $500 \mathrm{sccm}$, cathode, and anode back pressure at 25 psig. Prior to the recording of the polarization curves, the MEA was stabilized at $0.6 \mathrm{~V}$ for $5 \mathrm{~h}$ in order to activate the MEA.

\section{RESULTS AND DISCUSSIONS}

3.1. Physical Characterizations. Figure 1 shows representative SEM and TEM images of the synthesized CNTs and CNx. From the SEM images (inserts of parts a and c of Figure 1), it can be seen that CNTs and CNx are obtained on the substrate with high density. TEM images illustrate the differences between CNTs and CNx. The morphology of CNTs is a tubular structure with hollow cores (as shown in part a of Figure 1), which differs remarkably from CNx. The CNx structure is divided into hollow sections separated by one to a few graphite layers; that is, $\mathrm{CNx}$ shows bamboolike structures with defined compartments or with bridging layers, as presented in part $\mathrm{c}$ of Figure 1. The special structure of $\mathrm{CNx}$ indicates that nitrogen atoms are successfully incorporated into the graphite matrix, ${ }^{31}$ which is confirmed by XPS results discussed later on. Both CNTs and $\mathrm{CNx}$ have uniform distributions in tube diameters. The tube diameter of CNTs is about $35-50 \mathrm{~nm}$, whereas $\mathrm{CNx}$ shows a much larger diameter, from 120 to $150 \mathrm{~nm}$. More important differences lie on the sidewalls revealed by the HRTEM images in parts $\mathrm{b}$ and $\mathrm{d}$ of Figure 1. The surface morphology and atomic arrangement of the CNTs are flat and ordered with fine graphite layers respectively, as shown in part b of Figure 1. However, the surface morphology and atomic arrangement of $\mathrm{CNx}$ become rough and disordered (part $\mathrm{d}$ of Figure 1). The disruptions and irregular curvatures in graphene stacking in $\mathrm{CNx}$ are due to the propensity of incorporated nitrogen to form pentagonal and hexagonal defects in the graphene layers. The introduction of such defects disrupts the planar hexagonal arrangement of carbon atoms in CNTs and results in the rough surface of $\mathrm{CNx}$.
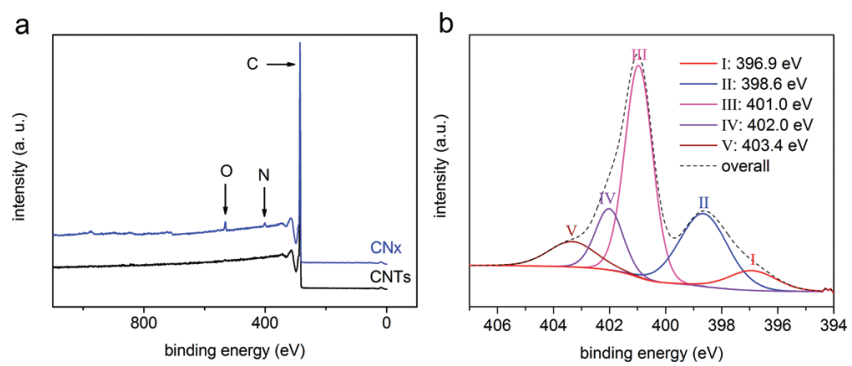

Figure 2. XPS spectra: (a) Survey scan of CNTs and CNx; (b) N 1s of $\mathrm{CNx}$.

To analyze the elemental composition as well as the chemicalbonding environment of doped nitrogen atoms, XPS measurements were conducted on CNTs and CNx. The XPS survey scans are depicted in part a of Figure 2. Both CNTs and CNx show a strong peak at $285 \mathrm{eV}$, which can be assigned to $\mathrm{C} 1 \mathrm{~s}$ from $\mathrm{sp}^{2}$ hybridized carbon in the nanotube. Compared with CNTs, CNx exhibits two extra peaks at 532 and $401 \mathrm{eV}$, which correspond to $\mathrm{O} 1 \mathrm{~s}$ and $\mathrm{N}$ 1s peaks, respectively. There exhibit many more edge planes on the surface of CNx compared to CNTs. The carbon atoms on the edge plane can be easily oxidized to oxygencontaining functionalities, ${ }^{32,33}$ and oxygen molecules can be also physisorbed onto the rough surface. This results in an $\mathrm{O} 1 \mathrm{~s}$ peak on the XPS spectrum of CNx. The existence of nitrogen peak confirms the successful incorporation of nitrogen atoms into the graphite matrix. The atomic concentration of $\mathrm{N}$ defined as $\mathrm{N} /(\mathrm{N}+\mathrm{C})$ was estimated by the peak area corrected by the sensitivity factors. ${ }^{34,35}$ The nitrogen concentration in the CNx is 8.4 atom \%. A fine-scanned $\mathrm{N}$ 1s peak (part b of Figure 2) was obtained to elucidate the chemical natures of the nitrogen in CNx. The asymmetric $\mathrm{N}$ 1s peak centered at $401 \mathrm{eV}$ can be deconvoluted into five peaks at 396.9, 398.6, 401.0, 402.0, and $403.4 \mathrm{eV}$ from low to high binding energy. They are ascribed as tetrahedral, pyridinic, graphitic, oxidized, and molecular nitrogen, respectively. ${ }^{28}$ Tetrahedral nitrogen is bonded to $\mathrm{sp}^{3} \mathrm{C}$ due to an undecomposed $\mathrm{N}-\mathrm{H}$ bond in the melamine precursor. ${ }^{36}$ Pyridinic nitrogen is bonded to two carbon atoms and donates one $\mathrm{p}$ electron to the aromatic $\pi$ system $(\mathrm{C}-\mathrm{N}=\mathrm{C}) .{ }^{37-39}$ Nitrogen-doping in the pyridinic sites is believed to be responsible for both the wall roughness and the interlinked morphologies. ${ }^{40}$ This is in good agreement with the TEM observations above. Graphitic nitrogen is a nitrogen atom, which replaces a carbon atom within a graphite plane and is bonded to three carbon atoms $(\underset{\mathrm{C}-\mathrm{N}-\mathrm{C}}{\mathrm{C}})^{37-39}$ Oxidized nitrogen is oxidized pyridinic nitrogen, which is bonded to two carbon atoms and one oxygen atom $\left(\begin{array}{c}\mathrm{O} \\ 1 \\ \mathrm{C}-\mathrm{N}-\mathrm{C}\end{array}\right) \cdot{ }^{41-44}$ Molecular $\mathrm{N}_{2}$ are nitrogen molecules adsorbed/intercalated at the carbon walls or trapped in the compartments, which has been confirmed by the X-ray absorption near-edge structure analysis ${ }^{45}$ and scanning transmission X-ray microscopy. ${ }^{46}$ From the peak areas, the doped nitrogen atoms are mainly pyridinic, graphitic, and oxidized nitrogen.

The carbon K-edge near-edge X-ray absorption fine structure (NEXAFS) was measured to compare the structures of CNTs and $\mathrm{CNx}$, as presented in Figure 3. The total electron yield (TEY) is surface sensitive with a typical probing depth of a few nanometers. According to the dipole-transition selection rule, all spectral features are caused by transitions from the $\mathrm{C} 1 \mathrm{~s}$ core level to p-like final unoccupied states. The two peaks at 286.5 and $292.8 \mathrm{eV}$ are attributed to the $\mathrm{C} 1 \mathrm{~s}$ to unoccupied states of $\mathrm{C}-\mathrm{C}$ 


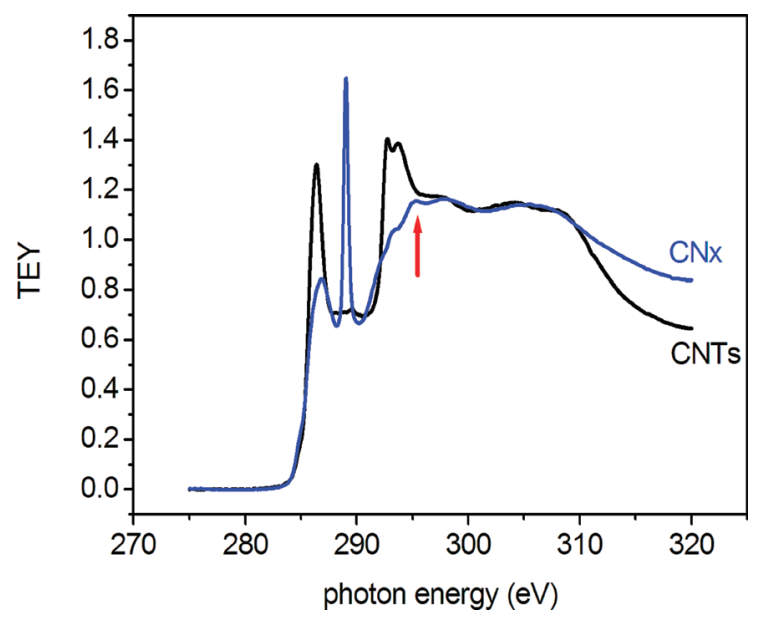

Figure 3. TEY of carbon K-edge NEXAFS of CNTs and CNx.

$\pi^{*}$ and $\mathrm{C}-\mathrm{C} \sigma^{*}$, respectively. ${ }^{47}$ The similar features in both spectra indicate a similar graphite structure in both samples. The differences between CNTs and CNx lies in the peak position and profile, and features in the region between the $\pi^{*}$ and $\sigma^{*}$ resonance. Several features are apparent. First, the $\pi^{*}$ is significant broadened and shifted to higher binding energy. This shift and accompanying broadening is due to the incorporation of $\mathrm{N}$ in the aromatic $(\pi)$ system, resulting in a shift to higher energy from the different chemical environment of $\mathrm{C}$ not directly bonded to the N. Second, there is a sharp peak at $289.1 \mathrm{eV}$, which is from defect sites in the graphite structure. ${ }^{46,47}$ It is reported that $\mathrm{N}$ dopants suppress the formation of $\mathrm{sp}^{2}$ carbon bonds because of strong bonds between $\mathrm{N}$ atoms and the neighboring host $\mathrm{C}$ atoms. ${ }^{48}$ The much higher intensity of the $289.1 \mathrm{eV}$ peak in $\mathrm{CNx}$ implies more defects in $\mathrm{CNx}$. This conclusion is consistent with the HRTEM observations and XPS results and was recently confirmed by STXM observation of an individual CNx. ${ }^{46}$ Finally, the spectroscopic features above the graphitic like $\sigma^{*}$ resonance exhibits an additional feature at $\sim 296.5 \mathrm{eV}$ (marked with an arrow). This is most likely due to the shape resonance (multiple scattering) arising from the $\mathrm{C}-\mathrm{N}$ bond.

The structural defectiveness caused by nitrogen doping is further evaluated quantitatively with Raman spectroscopy (Figure 4). The analysis of the peak positions and intensities gives information about the changes of the structural characteristics of the samples, namely graphite layer defectiveness, resulting from nitrogen doping. Both samples exhibit two strong bands near 1348 and 1579 $\mathrm{cm}^{-1}$, corresponding to the $\mathrm{D}$ - and G-bands, respectively. ${ }^{49}$ The G-band indicates the presence of crystalline graphite carbon, whereas the D-band is attributed to disorders in the graphite structure. The $\mathrm{D}^{\prime}$-band, which is a shoulder of the G-band at a higher frequency, corresponds to second-order Raman scattering from the variation of the $\mathrm{D}$-band. The ratio of the intensities of the two bands $\left(I_{\mathrm{D}} / I_{\mathrm{G}}\right)$ is an indicator of the degree of disorder within the samples. ${ }^{49}$ The $I_{\mathrm{D}} / I_{\mathrm{G}}$ ratios for CNTs and $\mathrm{CNx}$ are 0.58 and 0.86 , respectively. The much higher $I_{\mathrm{D}} / I_{\mathrm{G}}$ ratio and $\mathrm{D}^{\prime}$ band intensity of $\mathrm{CNx}$ implies the higher defectiveness of the graphitelike layers by nitrogen doping. Therefore, Raman results agree well with the above conclusion that $\mathrm{CNx}$ contains more defects than CNTs.

To use CNTs and CNx as catalyst supports, Pt nanoparticles were deposited on them. Figure 5 reveals the dispersion of $\mathrm{Pt}$ nanoparticles on CNTs and CNx, and the corresponding particle

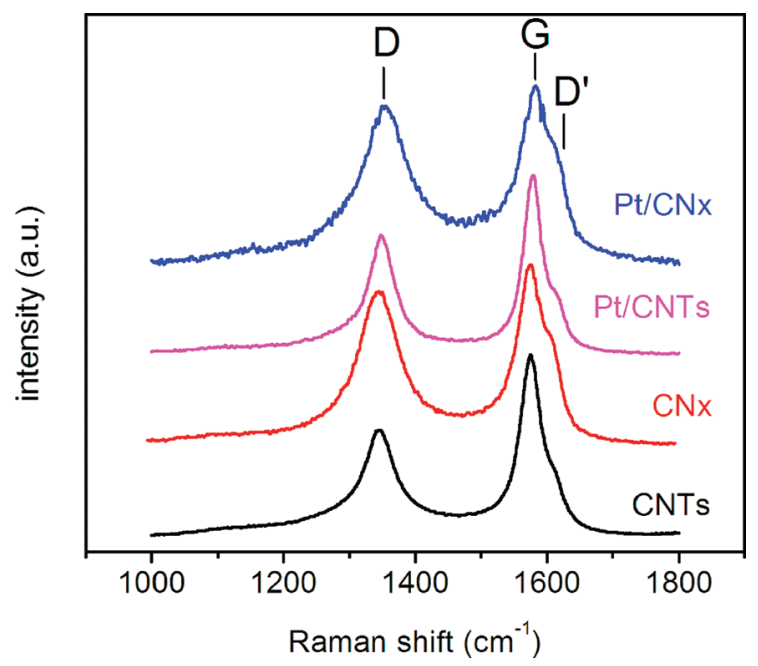

Figure 4. Raman spectra of CNTs, CNx, Pt/CNTs, and Pt/CNx (all the spectra are normalized to the G-band intensity).
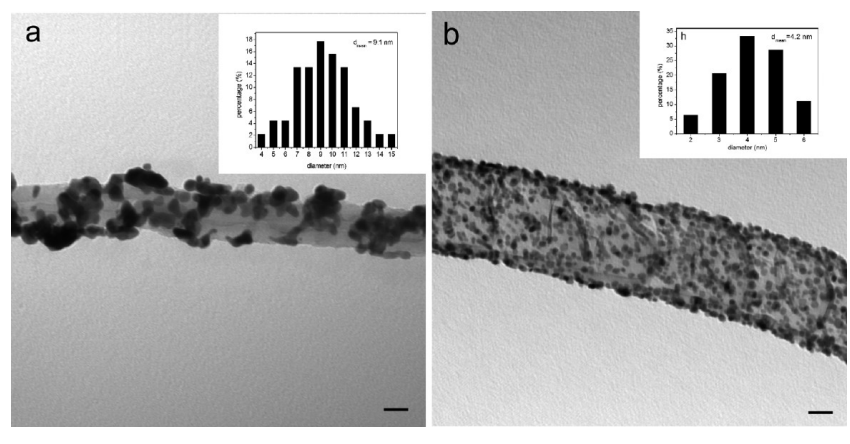

Figure 5. TEM images and size distribution histograms (inserts) of $\mathrm{Pt}$ nanoparticles deposited on CNTs (a) and $\mathrm{CNx}$ (b), scale bars are in $20 \mathrm{~nm}$.

size distribution histograms. On CNTs, the Pt nanoparticles size is distributed from 4 to $15 \mathrm{~nm}$, whereas Pt nanoparticles on $\mathrm{CNx}$ show a uniform dispersion from 2 to $6 \mathrm{~nm}$. The mean size of $\mathrm{Pt} / \mathrm{CNx}$ is $4.2 \mathrm{~nm}$, which is much smaller than that of $\mathrm{Pt} / \mathrm{CNTs}$, $9.1 \mathrm{~nm}$ (as listed in Table 1). Thus, Pt nanoparticles with a denser population were obtained on $\mathrm{CNx}$, with no evidence of agglomeration. In comparison, Pt nanoparticles aggregated into large clusters on CNTs and some surfaces of CNTs are free of Pt nanoparticle coverage. Because the deposition of Pt nanoparticles on the two supports was conducted under the same conditions, the difference in the dispersion behavior must come from the difference between these two supports. These results suggest that nitrogen doping into CNTs can affect the particle size and distribution of $\mathrm{Pt}$ during the reduction of $\mathrm{H}_{2} \mathrm{PtCl}_{6} \cdot 6 \mathrm{H}_{2} \mathrm{O}$ by ethylene glycol.

Studies have shown that nitrogen doping not only facilitates the high dispersion of $\mathrm{Pt}$ nanoparticles on the carbon surface but also results in a stronger interaction between $\mathrm{Pt}$ and the supports. ${ }^{50}$ First of all, the presence of the homogeneously distributed nitrogen species on the surfaces of $\mathrm{CNx}$ effectively provides nucleation sites and thus promotes a higher dispersion of $\mathrm{Pt}$ nanoparticles. Our previous study indicates that Pt prefers to nucleate along the kinks on the $\mathrm{CNx}$ surface, where nitrogen atoms are located. ${ }^{51}$ Second, there are more disorders on the surface of CNx than CNTs (as demonstrated by HRTEM 
Table 1. Particle Size, Electrochemical Parameters, and Catalytic Performances of Pt/CNTs and Pt/CNx

\begin{tabular}{cccccccc} 
average & $\begin{array}{c}\text { ECSA } \\
\left(\mathrm{m}^{2} / \mathrm{gPt}\right)\end{array}$ & $\begin{array}{c}\text { half-wave potential } \\
\text { of ORR }(\mathrm{V})\end{array}$ & $\begin{array}{c}\text { kinetic current density } \\
\text { of ORR at } 0.9 \mathrm{~V}(\mathrm{~mA})\end{array}$ & $\begin{array}{c}\text { OCV } \\
(\mathrm{V})\end{array}$ & $\begin{array}{c}\text { current density } \\
\text { at } 0.8 \mathrm{~V}\left(\mathrm{~A} / \mathrm{cm}^{2}\right)\end{array}$ & $\begin{array}{c}\text { maximum power } \\
\text { density }\left(\mathrm{w} / \mathrm{cm}^{2}\right)\end{array}$ \\
$\begin{array}{c}\mathrm{Pt} / \\
\mathrm{CNTs}\end{array}$ & 9.1 & 26.1 & 0.812 & 0.167 & 0.90 & 0.144 & 0.470 \\
$\mathrm{Pt} / \mathrm{CNx}$ & 4.2 & 41.8 & 0.844 & 0.332 & 0.93 & 0.230 & 0.876 \\
\hline
\end{tabular}
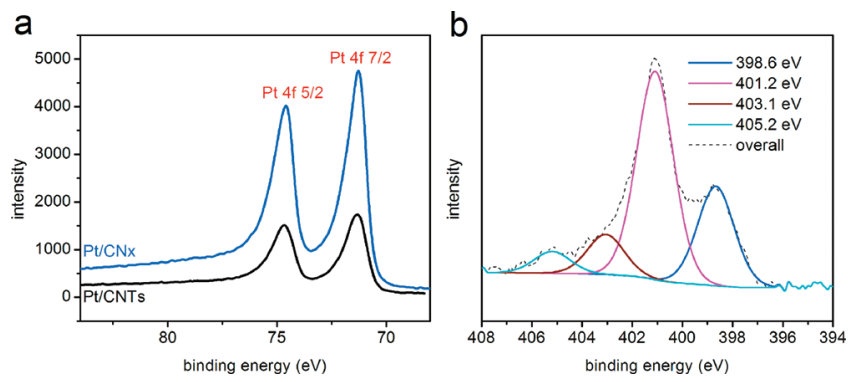

Figure 6. XPS spectra of Pt/CNx: Pt $4 \mathrm{f}(\mathrm{a})$ and N1s (b).

images, NEXAFS and Raman spectroscopy above). The surface defects induced by $\mathrm{N}$-doping almost certainly increases the interaction between $\mathrm{Pt}$ nanoparticles and the surface via $\mathrm{Pt}-$ $\mathrm{N}(\mathrm{O})$ mediated interaction, immobilizing the Pt nanoparticles. Third, nitrogen doping results in an improvement in hydrophilicity and wettability of $\mathrm{CNx}^{52}$ The enhanced access of solvated and charged $\mathrm{PtCl}_{6}{ }^{2-}$ ions to the $\mathrm{CNx}$ surface can be associated with the superior dispersion of Pt nanoparticles and the avoidance of agglomeration. It is found that $\mathrm{CNx}$ is easier to disperse in the solution during experiments. Finally, the electronic structure of $\mathrm{CNx}$ is modified by nitrogen doping. Nitrogen atoms doped into CNTs are most likely to be electron donors ${ }^{53}$ and result in chemically active localized areas in $\mathrm{CNx}$ with a higher electron density. ${ }^{54}$ This increase in reductive sites or high local electron density can be explained by the pyridinic, oxidized, and graphitic nitrogen. ${ }^{55}$ Thus, $\mathrm{CNx}$ could enhance the reduction of $\mathrm{H}_{2} \mathrm{PtCl}_{6}$ and lead to a high dispersion of $\mathrm{Pt}$ nanoparticles. All of the above factors including surface nitrogen functionalities, surface disorders, improved hydrophilicity, and modified electronic structure contribute to the good dispersion and immobilization of $\mathrm{Pt}$ nanoparticles on the CNx surface.

XPS spectra were collected to further confirm the deposition of Pt on CNTs and CNx. The survey scans of Pt/CNTs and $\mathrm{Pt} / \mathrm{CNx}$ show the signals of the corresponding elements (Figures S1 and S2 of the Supporting Information). Two distinct sharp Pt (4f 7/2) and $\mathrm{Pt}(4 \mathrm{f} \mathrm{5/2)}$ peaks around 71.00 and $74.34 \mathrm{eV}$ respectively are clearly observed on $\mathrm{Pt} / \mathrm{CNT}$ s and $\mathrm{Pt} / \mathrm{CNx}$ (part a of Figure 6). These are typical values for zero-valence $\mathrm{Pt}$, indicating that the deposited $\mathrm{Pt}$ is metallic.

The fine-scanned $\mathrm{N}$ 1s peak of $\mathrm{CNx}$ after Pt deposition was also analyzed in part b of Figure 6. Compared with the chemical components of nitrogen in pristine $\mathrm{CNx}$ discussed above, tetrahedral and oxidized nitrogen at 396.9 and $402.0 \mathrm{eV}$ disappear. Pyridinic, graphite and molecular nitrogen at 398.6, 401.2 , and $403.1 \mathrm{eV}$ respectively are still observed. A new peak at $405.2 \mathrm{eV}$ appears. This new peak can be ascribed to chemisorbed nitrogen oxides. ${ }^{44}$ It seems that the tetrahedral and oxidized nitrogen convert to chemisorbed nitrogen oxides after Pt deposition. However, more work need to be done to elucidate this phenomenon.

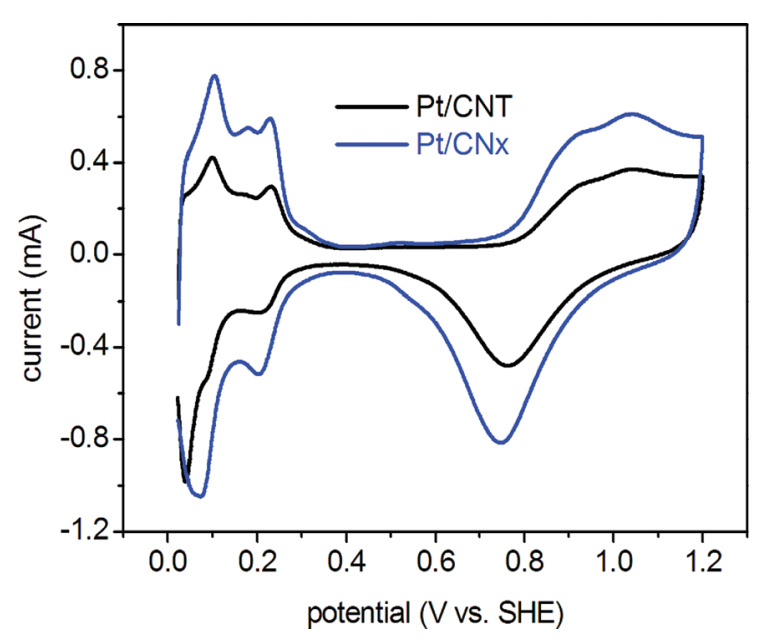

Figure 7. Cyclic voltammograms of $\mathrm{Pt} / \mathrm{CNTs}$ and $\mathrm{Pt} / \mathrm{CNx}$ in $\mathrm{Ar}$ saturated $0.5 \mathrm{M} \mathrm{H}_{2} \mathrm{SO}_{4}$ at $50 \mathrm{mV} / \mathrm{s}$.

The Raman spectra of Pt/CNTs and Pt/CNx were also taken in comparison of the spectra of the original CNTs and CNx (Figure 4). The similar features suggest that the deposition of $\mathrm{Pt}$ nanoparticles cause little changes to the CNTs or CNx. However, the $\mathrm{D}$ - and $\mathrm{D}^{\prime}$-band intensities increase with $\mathrm{Pt}$ deposition in relative with the G-band intensity. The $I_{\mathrm{D}} / I_{\mathrm{G}}$ ratios of $\mathrm{Pt} / \mathrm{CNTs}$ and $\mathrm{Pt} / \mathrm{CNx}$ are 0.67 and 0.89 , increasing from 0.58 and 0.86 for $\mathrm{CNTs}$ and $\mathrm{CNx}$, respectively. Because of the preferential deposition of Pt on the defective sites on the surface of CNTs or CNx, a selective surface-enhancement effect of the defect-induced Raman signal (D and $\mathrm{D}^{\prime}$-band) occurs. ${ }^{56,57}$

3.2. Electrochemical Characterizations. To show that the enhanced dispersion of $\mathrm{Pt}$ nanoparticles on $\mathrm{CNx}$ improves their catalytic activity toward the ORR, electrochemical characterizations were conducted, in comparison with Pt/CNTs. The cyclic voltammograms of both $\mathrm{Pt} / \mathrm{CNT}$ and $\mathrm{Pt} / \mathrm{CNx}$ are presented in Figure 7. Typical CV curves of $\mathrm{Pt}$ are obtained, with $\mathrm{H}_{2}$ adsorption/desorption regions and $\mathrm{Pt}$ oxidation/reduction peaks. The electrochemical surface area (ECSA) of Pt is calculated from the charges of $\mathrm{H}_{2}$ adsorption/desorption peaks, assuming a surface density of $1.3 \times 10^{15}$ atom $/ \mathrm{cm}^{2}$ for polycrystalline Pt. ${ }^{11} \mathrm{Pt} / \mathrm{CNx}$ shows a larger ECSA of $41.8 \mathrm{~m}^{2} / \mathrm{g}_{\mathrm{Pt}}$ compared to that of $\mathrm{Pt} / \mathrm{CNT}$, whose ECSA is $26.1 \mathrm{~m}^{2} / \mathrm{g}_{\mathrm{Pt}}$ (as listed in Table 1). Higher ECSA of Pt/CNx than Pt/CNTs must originate from the higher dispersion of $\mathrm{Pt}$ nanoparticles and smaller Pt particle size. It will be responsible for the better electrochemical catalytic activity discussed below.

Figure 8 shows The RRDE tests for ORR on the Pt/CNTs and $\mathrm{Pt} / \mathrm{CNx}$ under the same experimental conditions. From Figure 8, the kinetic current density reaches a plateau at low potential, which implies that ORR is diffusion-controlled. At high potential region, the ORR is under mixed diffusion-kinetic control. The half-wave potential, an indicator of activity toward ORR, of 


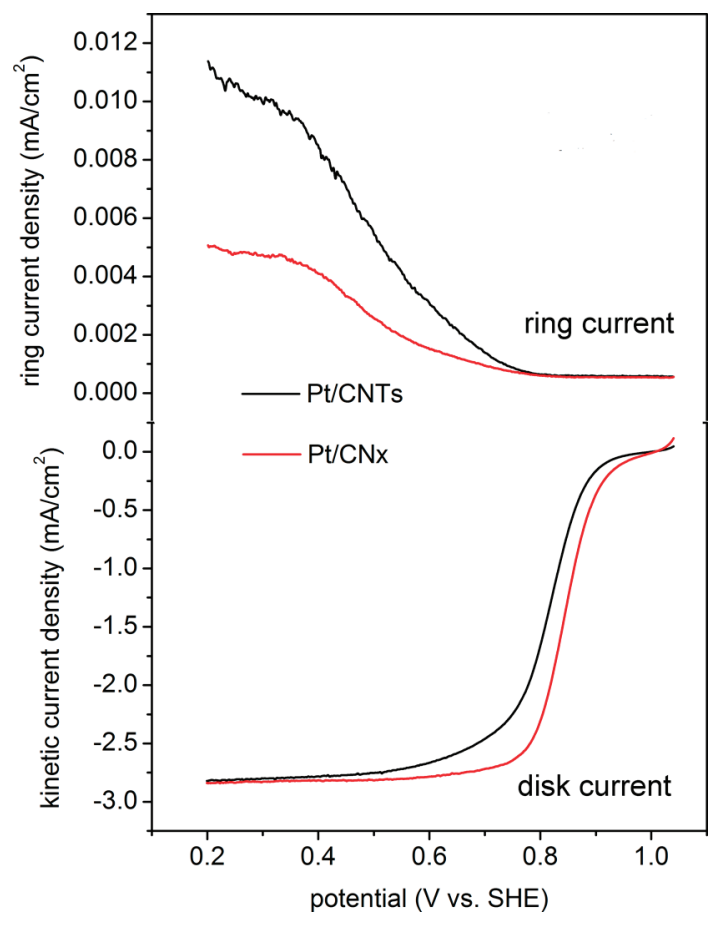

Figure 8. RRDE tests toward ORR on $\mathrm{Pt} / \mathrm{CNTs}$ and $\mathrm{Pt} / \mathrm{CNx}$ in the cathodic sweep at $1600 \mathrm{rpm}$ in $\mathrm{O}_{2}$ saturated $0.5 \mathrm{M} \mathrm{H}_{2} \mathrm{SO}_{4}$ at $5 \mathrm{mV} / \mathrm{s}$ and $25^{\circ} \mathrm{C}$.

Pt/CNx shifts positively by $32 \mathrm{mV}$, compared with Pt/CNTs as listed in Table 1. Thus, nitrogen doping on the supports enhances the electrocatalytic activity of the deposited Pt toward ORR. The substantial enhancement for ORR can be obviously credited to the larger ECSA as demonstrated above. The ECSA of $\mathrm{Pt} / \mathrm{CNx}$ is 1.60 times of that of Pt/CNTs, as listed in Table 1. At $0.9 \mathrm{~V}$, the kinetic current density of $\mathrm{Pt} / \mathrm{CNx}$ is $0.332 \mathrm{~mA}$, whereas that of Pt/CNTs is $0.167 \mathrm{~mA}$. That is, the kinetic current (at $0.9 \mathrm{~V}$ ) of $\mathrm{Pt} / \mathrm{CNx}$ is 1.99 times higher than that of Pt/CNTs. The specific activity, defined by kinetic current at $0.9 \mathrm{~V}$ divided by ECSA, of Pt/CNx is 1.34 times of $\mathrm{Pt} / \mathrm{CNT}$. Therefore, nitrogen doping not only increases the ECSA, but also improves the intrinsic electrocatalytic activity toward ORR.

It is well-known that the ORR can proceed by two pathways, (i) a two-electron reduction to $\mathrm{H}_{2} \mathrm{O}_{2}$ (R1), and (ii) a fourelectron reduction to $\mathrm{H}_{2} \mathrm{O}(\mathrm{R} 2)$. The ring current

$$
\begin{aligned}
& \mathrm{O}_{2}+2 \mathrm{H}^{+}+2 \mathrm{e}^{-} \rightarrow \mathrm{H}_{2} \mathrm{O}_{2} \\
& \mathrm{O}_{2}+4 \mathrm{H}^{+}+4 \mathrm{e}^{-} \rightarrow 2 \mathrm{H}_{2} \mathrm{O}
\end{aligned}
$$

density (Figure 8 ), at $1.2 \mathrm{~V}$, corresponds to the fraction of $\mathrm{H}_{2} \mathrm{O}_{2}$ during ORR. Compared with the disk current density, the ring current density is negligible, which indicates that the ORR mainly goes through a four-electron pathway. The ring current density of $\mathrm{Pt} / \mathrm{CNx}$ is smaller than that of Pt/CNTs, which means that Pt/ $\mathrm{CNx}$ favors a four-electron pathway more than the Pt/CNTs. It is well recognized that $\mathrm{H}_{2} \mathrm{O}_{2}$ accelerates the degradation of the Nafion electrolyte membrane in the PEMFC. ${ }^{2}$ Hence, a reduced production of $\mathrm{H}_{2} \mathrm{O}_{2}$ in $\mathrm{Pt} / \mathrm{CNx}$ can increase the durability of PEMFCs. This is another benefit with $\mathrm{CNx}$ as the Pt supports.

It has been shown that $\mathrm{CNx}$ itself can act as an electrocatalyst for ORR. ${ }^{19,20}$ As shown in Figure S3 in Supporting Information, CNx shows a higher activity for ORR than CNTs. However, the

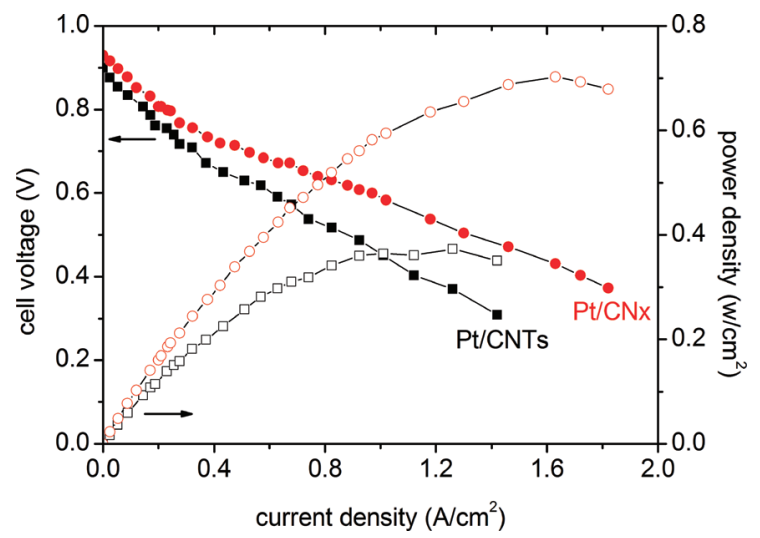

Figure 9. Comparison of single fuel cell performances with Pt/CNTs and $\mathrm{Pt} / \mathrm{CNx}$ as the cathode catalysts at a Pt loading of $0.2 \mathrm{mg} / \mathrm{cm}^{2}$. Commercial gas diffusion electrode $\left(0.5 \mathrm{mg}_{\mathrm{Pt}} / \mathrm{cm}^{2}, \mathrm{E}\right.$-TEK) as the anode; $\mathrm{H}_{2} / \mathrm{O}_{2}$ at $80{ }^{\circ} \mathrm{C}$; Nafion 112 membrane; $25 / 25$ psig anode and cathode back pressure respectively.

contributions from the support materials count for little in comparison with the Pt catalysts. The improved activity of $\mathrm{Pt} /$ $\mathrm{CNx}$ can be also ascribed to the specific interaction between $\mathrm{CNx}$ and the overlying Pt catalysts. ${ }^{58}$ This interaction can result in modifications to the electronic structure of the overlying $\mathrm{Pt}$ nanoparticles which in turn changes their catalytic activity. ${ }^{50}$ $\mathrm{CNx}$ is most likely to be an electron donor. When deposited with $\mathrm{Pt}$, the electron transfer from the $\mathrm{CNx}$ support to the unfilled orbitals of Pt could occur via the nitrogen group. This process would lead to the higher electron density of Pt nanoparticles, keep a clean metallic surface, and thus enhance the electrocatalytic activity. The Pt $4 \mathrm{f}$ peak shift in XPS, ${ }^{59}$ first principle calculations on binding energy between $\mathrm{Pt}$ and $\mathrm{CNx}^{25,26}$ and our previous durability study of $\mathrm{Pt} / \mathrm{CNx}^{27}$ all indicate a strong metal-support interaction between $\mathrm{CNx}$ and the overlying $\mathrm{Pt}$ nanoparticles.

3.3. Fuel Cell Performances. The $\mathrm{H}_{2} / \mathrm{O}_{2}$ fuel cell performances of $\mathrm{Pt} / \mathrm{CNT}$ and $\mathrm{Pt} / \mathrm{CNx}$ as the cathode catalysts are shown in Figure 9. Pt/CNx showed a better performance than Pt/CNTs. The comparison of the performances is listed in Table 1. Pt/CNx exhibited an open circuit voltage (OCV) of $0.93 \mathrm{~V}$, which is higher than $0.9 \mathrm{~V}$ of Pt/CNTs. At the cell voltage of $0.8 \mathrm{~V}, \mathrm{Pt} / \mathrm{CNT}$ s have a current density of $0.144 \mathrm{~A} / \mathrm{cm}^{2}$, whereas $\mathrm{Pt} / \mathrm{CNx}$ is $0.230 \mathrm{~A} / \mathrm{cm}^{2}$, with an improvement of $59.7 \%$. Furthermore, the maximum power density of $\mathrm{Pt} / \mathrm{CNx}$ is 0.876 $\mathrm{W} / \mathrm{cm}^{2}$, which is larger than $0.470 \mathrm{~W} / \mathrm{cm}^{2}$ of Pt/CNTs. Because the same anode catalyst and membrane were used in the tests and the cathode dominates the fuel cell performance, it can be concluded that $\mathrm{Pt} / \mathrm{CNx}$ is a better cathode catalyst than Pt/CNTs. That is, CNx is superior to CNTs as the Pt supports. The results are in good agreement with the RRDE tests above. And, the mechanism for the enhancement in fuel cell performance can be explained in the same way as above.

\section{CONCLUSIONS}

CNTs and CNx have been synthesized with the FCCVD method under similar conditions for a comparative test. The structure of $\mathrm{CNx}$ is changed considerably by the doping of nitrogen into the graphene matrix. XPS, NEXAFS and Raman characterizations reveal the structural differences between CNTs and $\mathrm{CNx}$ in details. With the ethylene glycol reduction method, $\mathrm{Pt}$ 
nanoparticles have been deposited on these two supports. $\mathrm{Pt} / \mathrm{CNx}$ shows a more uniform dispersion with smaller particle size than Pt/CNTs. Pt/CNx exhibits higher catalytic activity toward ORR than Pt/CNTs, as indicated by a larger kinetic current, higher half-wave potential, and higher four-electron transfer efficiency to $\mathrm{H}_{2} \mathrm{O}$. Pt/CNx, as a cathode catalyst, also shows higher fuel cell performance in a single cell test than that of Pt/CNTs.

\section{ASSOCIATED CONTENT}

S Supporting Information. XPS survey scans of Pt/CNTs and Pt/CNTs; ORR activities of CNTs, CNx, Pt/CNTs, and Pt/ $\mathrm{CNx}$. This material is available free of charge via the Internet at http://pubs.acs.org.

\section{AUTHOR INFORMATION}

\section{Corresponding Author}

*E-mail: xsun@eng.uwo.ca. Tel: +1-519-6612111, Ext. 87759. Fax: +1-519-6613020.

\section{ACKNOWLEDGMENT}

This research was supported by Natural Sciences and Engineering Research Council of Canada (NSERC), Ballard Power System Inc., Canada Research Chair (CRC) Program, Canada Foundation for Innovation (CFI), Ontario Research Fund (ORF), Ontario Early Researcher Award (ERA) and the University of Western Ontario. The Canadian Light Source (CLS) is supported by NSERC, NRC, CIHR, and the University of Saskatchewan. We wish to thank Mike Sun for his helpful suggestions.

\section{REFERENCES}

(1) Larminie, J.; Dicks, A. Fuel Cell Systems Explained, 2nd ed.; West Sussex, England: John Wiley \& Sons Ltd., 2003.

(2) Borup, R.; Meyers, J.; Pivovar, Br.; Kim, Y. S.; Mukundan, R.; Garland, N.; Myers, D.; Wilson, M.; Garzon, F.; Wood, D.; Zelenay, P.; More, K.; Stroh, K.; Zawodzinski, T.; Boncella, J.; McGrath, J. E.; Inaba, M.; Miyatake, K.; Hori, M.; Ota, K.; Ogumi, Z.; Miyata, S.; Nishikata, A.; Siroma, Z.; Uchimoto, Y.; Yasuda, K.; kimijima, K.; Iwashita, N. Chem. Rev. 2007, 107, 3904.

(3) Gasteiger, H. A.; Kocha, S. S.; Sompalli, B.; Wagner, F. T. Appl. Catal., B 2005, 56, 9.

(4) Yu, X.; Ye, S. J. Power Sources 2007, 172, 145.

(5) Thompson, S. D.; Jordan, L. R.; Forsyth, M. Electrochim. Acta 2001, 46, 1657.

(6) Kinoshita, K. Carbon: Electrochemical and Physicochemical Properties; New York: John Wiley \& Sons, 1988.

(7) Roen, L. M.; Paik, C. H.; Jarvi, T. D. Electrochem. Solid-State Lett. 2004, 7, A19.

(8) Shao, Y.; Wang, J.; Kou, R.; Engelhard, M.; Liu, J.; Wang, Y.; Lin, Y. Electrochim. Acta 2009, 54, 3109.

(9) Li, L.; Xing, Y. J. Electrochem. Soc. 2006, 153, A1823.

(10) Wang, X.; Li, W.; Chen, Z.; Waje, M.; Yan, Y. J. Power Sources 2006, 158, 154.

(11) Saha, M. S.; Li, R.; Sun, X. J. Power Sources 2008, 177, 314.

(12) Wang, X.; Waje, M.; Yan, Y. Electrochem. Solid-State Lett. 2005, $8, \mathrm{~A} 42$.

(13) Zhang, S.; Shao, Y.; Yin, G.; Lin, Y. J. Mater. Chem. 2010, $20,2826$.

(14) Wang, S.; Jiang, S. P.; Wang, X. Nanotechnology 2008, 19, 265601.

(15) Yang, J.; Goenaga, G.; Call, A.; Liuz, D. Electrochem. Solid-State Lett. 2010, 13, B55.

(16) Shao, Y.; Yin, G.; Gao, Y.; Shi, P. J. Electrochem. Soc. 2006, 153, A1093.
(17) Lee, K.; Zhang, J.; Wang, H.; Wilkinson, D. P. J. Appl. Electrochem. 2006, 36, 507.

(18) Zamudio, A.; Elias, A. L.; Rodriguez-Manzo, J. A.; Lopez-Urias, F.; Rodriguez-Gattorno, G.; Lupo, F.; Ruhle, M.; Smith, D. J.; Terrones, H.; Diaz, D.; Terrones, M. Small 2006, 2, 346.

(19) Lefevre, M.; Proietti, E.; Jaouen, F.; Dodelet, J. Science 2009, 324,71 .

(20) Bezerra, C. W.; Zhang, L.; Lee, K.; Liu, H.; Marques, A. L.; Marques, E.; Wang, H.; Zhang, J. Electrochim. Acta 2008, 50, 4937.

(21) Saha, M. S.; Li, R.; Sun, X.; Ye, S. Electrochem. Commun. 2009, $11,438$.

(22) Yue, B.; Ma, Y.; Tao, H.; Yu, L.; Jian, G.; Wang, X.; Wang, X.; Lu, Y.; Hu, Z. J. Mater. Chem. 2008, 18, 1747.

(23) Choi, B.; Yoon, H.; Park, I.; Jang, J.; Sung, Y. Carbon 2007, 45, 2496.

(24) Sun, C.; Chen, L.; Su, M.; Hong, L.; Chyan, O.; Hsu, C.; Chen, K.; Chang, T.; Chang, L. Chem. Mater. 2005, 17, 3749.

(25) Li, Y.; Hung, T.; Chen, C. Carbon 2009, 47, 850.

(26) An, W.; Turner, C. H. J. Phys. Chem. C 2009, 113, 7069.

(27) Chen, Y.; Wang, J.; Liu, H.; Li, R.; Sun, X.; Ye, S.; Knights, S. Electrochem. Commun. 2009, 11, 2071.

(28) Liu, H.; Zhang, Y.; Li, R.; Sun, X.; Désilets, S.; Abou-Rachid, H.; Jaidann, M.; Lussier, L. Carbon 2010, 48, 1498.

(29) Bock, C.; Paquet, C.; Couillard, M.; Botton, G. A.; MacDougall, B. R. J. Am. Chem. Soc. 2004, 126, 8028.

(30) Murthi, V. S.; Urian, R. C.; Mukerjee, S. J. Phys. Chem. B 2004, $108,11011$.

(31) Wang, E. G. J. Mater. Res. 2006, 21, 2767.

(32) Jianga, W.; Nadeaub, G.; Zaghib, K.; Kinoshita, K. Thermochim. Acta 2000, 351, 85 .

(33) Shalagina, A. E.; Ismagilov, Z. R.; Podyacheva, O. Yu.; Kvon, R. I.; Ushakov, V. A. Carbon 2007, 45, 1808.

(34) Nath, M.; Satishkumar, B. C.; Govindaraj, A.; Vinod, C. P.; Rao, C. Chem. Phys. Lett. 2000, 322, 333.

(35) Kim, S. Y.; Lee, J.; Na, C. W.; Park, J.; Seo, K.; Kim, B. Chem. Phys. Lett. 2005, 413, 300.

(36) Ghosh, K.; Kumar, M.; Maruyama, T.; Ando, Y. Carbon 2009, 47, 1565 .

(37) Tao, X. Y.; Zhang, X. B.; Sun, F. Y.; Cheng, J. P.; Liu, F.; Luo, Z. Q. Diamond Relat. Mater. 2007, 16, 425.

(38) Zhang, G. Y.; Ma, X. C.; Zhong, D. Y.; Wang, E. G. J. Appl. Phys. 2002, 91, 9324.

(39) Morant, C.; Andrey, J.; Prieto, P.; Mendiola, D.; Sanz, J. M.; Elizalde, E. Phys. Status Solidi A 2006, 203, 1069.

(40) Liu, J.; Webster, S.; Carroll, D. L. J. Phys. Chem. B 2005, 109, 15769 .

(41) Matter, P. H.; Zhang, L.; Ozkan, U. S. J. Catal. 2006, 239, 83.

(42) Pels, J. R.; Kapteijn, F.; Moulijn, J. A.; Zhu, Q.; Thomas, K. M. Carbon 1995, 33, 1641.

(43) Casanovas, J.; Ricart, J. M.; Rubio, J.; Illas, F.; Jimenez-Meteos, J. M. J. Am. Chem. Soc. 1996, 118, 8071.

(44) Biniak, S.; Szymanski, G.; Siedlewski, J.; Swiatkowsky, A. Carbon 1997, 35, 1799.

(45) Choi, H. C.; Bae, S. Y.; Jang, W.; Park, J.; Song, H. J.; Shin, H.; Jung, H.; Ahn, J. J. Phys. Chem. B 2005, 109, 1683.

(46) Zhou, J.; Wang, J.; Liu, H.; Banis, M. N.; Sun, X.; Sham, T. J. Phys. Chem. Lett. 2010, 1, 1709.

(47) Tang, Y. H.; Sham, T. K.; Hu, Y. F.; Lee, C. S.; Lee, S. T. Chem. Phys. Lett. 2002, 366, 636.

(48) Pong, W. F.; Yueh, C. L.; Chang, Y. D.; Tsai, M. H.; Chang, Y. K.; Chen, Y. Y.; Lee, J. F.; Wei, S. L.; Wen, C. Y.; Chen, L. C.; Chen, K. H.; Ling, I. N.; Chengh, H. F. J. Synchrotron Rad. 2001, 8, 145.

(49) Chuang, C. C.; Huang, J. H.; Chen, W. J.; Lee, C. C.; Chang, Y. Y. Diamond Relat. Mater. 2004, 13, 1012.

(50) Shao, Y.; Sui, J.; Yin, G.; Gao, Y. Appl. Catal. A: Environmental 2008, 79, 89.

(51) Sun, S.; Zhang, G.; Zhong, Y.; Liu, H.; Li, R.; Zhou, X.; Sun, X. Chem. Commun. 2009, 7048. 
(52) Zhou, Y.; Pasquarelli, R.; Holme, T.; Berry, J.; Ginleyc, D.; O'Hayre, R. J. Mater. Chem. 2009, 19, 7830.

(53) Strelko, V. V.; Kuts, V. S.; Throwerb, P. A. Carbon 2000, 38, 1499.

(54) Nevidomskyy, A. H.; Csányi, G.; Payne, M. C. Phys. Rev. Lett. 2003, 91, 105502.

(55) Biniak, S.; Szymanski, G.; Siedlewski, J.; Swiatkowski, A. Carbon 1997, 35, 1799.

(56) Lin, Y.; Watson, K. A.; Fallbach, M. J.; Ghose, S.; Smith, J. G.; Delozier, D. M.; Cao, W.; Crooks, R. E.; Connell, J. W. ACS Nano 2009, 3, 871 .

(57) Hao, Q.; Juluri, B. K.; Zheng, Y. B.; Wang, B.; Chiang, I.; Jensen, L.; Crespi, V.; Eklund, P. C.; Huang, T. J. J. Phys. Chem. C 2010, 114, 18059.

(58) Ye, S.; Vijh, A. K.; Dao, L. H. J. Electrochem. Soc. 1997, 144, 90.

(59) Lei, Z.; An, L.; Dang, L.; Zhao, M.; Shi, J.; Bai, S.; Cao, Y. Microporous Mesoporous Mater. 2009, 119, 30. 